\title{
The Animal Issue Revisited: Tertium Genus or Subject
}

\author{
Jose Luis Bonifácio Ramos \\ Faculty of Law, University of Lisbon, Lisbon, Portugal
}

Email address:

jlramos@fd.ulisboa.pt

To cite this article:

Jose Luis Bonifácio Ramos. The Animal Issue Revisited: Tertium Genus or Subject. International Journal of Law and Society. Vol. 4, No. 3, 2021, pp. 177-186. doi: 10.11648/j.ijls.20210403.14

Received: July 22, 2021; Accepted: August 5, 2021; Published: August 18, 2021

\begin{abstract}
The article seeks to reflect on the animal theme. Not only a brief perspective of legal historical evolution, but, in particular, about the legal regime emerging from the 2017 reform of the Portuguese Civil Code. In our opinion, the reform was timid, confusing and disappointing. In large part, the applicable regime turns out to be, in large part, the regime of things, applicable on a subsidiary basis. Furthermore, with regard to the right to property, it no longer applies only to things, admitting ownership of animals. However, respect for animal welfare, namely the guarantee of access to water and food, as well as the guarantee of access to medical and veterinary care, including prophylactic, identification and vaccination measures, coexist poorly with the property itself. On the other hand, with regard to the occupation, perplexities remain. Especially with regard to the content of articles 1318 and $1323 \mathrm{CC}$. And, of course, with regard to the implications arising from the legal nature of the animal. In fact, it matters to know if we are dealing with a thing, an object, a tertium genus or a subject of rights. On the other hand, apart from the options of the Portuguese legislator, we analyze, very briefly, recent theories, whose common denominator is a clear defense and affirmation of animal rights.
\end{abstract}

Keywords: Animal, Tertium Genus, Animal Welbeing, Anthropocentrism, Speciesism, Trust, Animal Rights, Zoopolis

\section{General Considerations}

After having already advanced with one set of reflections on the problems underlying the animal theme, specifically regarding their ownership and respective juridical nature, within the scope of the 2011 publication of the Studies Dedicated to Professor Luís Carvalho Fernandes, there is now every justification for returning to this subject. Not only because a decade has lapsed since its writing but also because the matters involved have very much jumped up the agenda. Not especially in keeping with how there is now a political party with a markedly pro-animal focus or because the media dedicate so much more space to the animal cause, this rather arises from the highly significant increase in the number of ethical, philosophical and juridical considerations posited over the course of this period. And, still furthermore, there have also been profound alterations made to positive law in Portugal. Effectively, following a restrictive, atavistic and prolonged inertia, the Portuguese parliament finally approved a juridical statute for animals in $2017^{1}$ which drove

${ }^{1}$ Cf. Law n ${ }^{\circ} 8 / 2017$ of 3 March corresponding modifications to the Civil Code, the Civil Process Code and the Penal Code. Our contribution shall be limited only to the sub-field of Civil Law, the Real Rights and focusing on two framing facets. On the one hand, there is the distinction between the thing and the animal. On the other hand, there is the assessment of the susceptibility of perceiving the animal as a true subject of rights.

\section{The Problematic in Presence}

The animal, as a living, non-rational being, has drawn the attention of Ethics, Philosophy and Law ever since classical times. However, this has not always converged around meanings seeking to dignify non-human living beings. Nevertheless, Plutarch expressed particular consideration for animals to the extent of rejecting the dichotomy between sentient and non-sentient animals ${ }^{2}$ as well as any type of violence or cruelty ${ }^{3}$. Under Roman law, on the contrary, the decline in the statute of animals was marked. In effect,

${ }^{2}$ Cf. Plutarch's Moralia, Cambridge, (Massachusetts), London, 1957, pp. 327 and fol.

${ }^{3}$ Cf. Plutarch's Moralia...op. cit., pp. 456 and fol. 
according to the Roman Digest, the animal was the equivalent of a moveable thing ${ }^{4}$, with only the need to identify as regards wild animals whether they were res nullius or the property of the owner of the soil, lake or lagoon hosting whatever the hunting or fishing activities ${ }^{5}[3,49]$.

Later, within the scope of distinguishing between people and animals, in order to establish a rule, this made renewed recourse to the category of inanimate objects. This trend would deepen and reach further under Germanic law. This started out with the dichotomy between Munt and Gewere 6 [21], afterwards, by means of the prescriptions of Sachsenspiegel, the purpose of the regulations in effect for hunting bring the animal and the thing into very close proximity ${ }^{7}$ [14]. Indeed, this directive was subsequently maintained both in the Allgemeines Landrecht ${ }^{8}$, as in the original version of the Civil $\operatorname{Cod}^{9}$ and as well as in the BGB itself $^{10}[33]$. As regards the case of Portuguese law, we may encounter similar orientations stipulated in the legal decrees issued by Manuel I ${ }^{11}$, Philip II of Spain (Philip I of Portugal) 12 and, at a later phase, in the Seabra Code ${ }^{13}$. Thus, this was to a general extent accepted by the doctrine of the period. In practice, Correa Telles defended this understanding in his position as regards the status of animals as being ownerless or as lost items ${ }^{14}$ [47]. In turn, according to Cabral de Moncada, the offspring of animals were perceived as the benefits of an immovable object ${ }^{15}[30]$.

It is worth clarifying, however, that the idea of distinguishing animals from inanimate things had already obtained significant impetus in the 18th century with the studies of Jeremy Bentham. Above all, he denounced the

\footnotetext{
${ }^{4}$ Cf. Digest, 41, 1, 7, 3 .

${ }^{5}$ According to one doctrinal current, land animals or fish, the subject to of hunting or fishing, were not res nullius, but belonged to the owner of the terrain, lake or lagoon. Cf. PIETRO BONFANTE, Corso di Diritto Romano, Vol. II, Milan, 1968, pp. 33 and fol. ALOIS VON BRINZ, Lehrbuch der Pandekten, Vol. I, 2nd ed., Erlangen, 1887, pp. 77 and fol.

${ }^{6}$ The Munt corresponds, first of all, to the Roman manus, consisting of the domain of the head of family, extending over all of the items wich are found within his possession. This included people and animals. Later, while Munt was destined to apply to the domain over free persons, Gewere incorporated slaves and other objects, such as the animals that were in the house or on the terrain belonging to the head of family. Cf. ANDREAS HEUSLER, Institutionen des deutschen Privatrechts, Vol. I, Leipzig, 1885, pp. 97 and fol.

${ }^{7}$ On the differences in the rules for hunting, mining and treasure-seeking in the Sachsenspiegel, see ERNST ECKSTEIN, "Das Schatz und Fundregal und seine Entwicklung in den deutschen Rechten" in Mitteilungen des Instituts für österreichische Geschichtsforschung, no. 31, 1910, pp. 193 and fol.

${ }^{8} \mathrm{Cf}$. ALR, II, 2.3.

${ }^{9} \mathrm{Cf}$. article 524 of the French Civil Code, in its original version.

${ }^{10}$ In addition to that stipulated by $\S \S 90,91$ and 92 , in accordance with that conceived by $\S 98$ and 99 , it would seem clear that the animals were, at best, products, benefits or parts of the fixed property. Within this scope, see OTTO PALANDT, Bürgerliches Gesetzbuch Kommentar, 47th ed., Munich, 1988, pp. 57 and fol.

${ }^{11}$ Cf. Ordenações Manuelinas, Book II, XV.

${ }^{12}$ Cf. Ordenações Filipinas, Book II, XXVI.

${ }^{13}$ Cf. Article 383 of the 1867 Civil Code.

${ }^{14}$ Cf. CORREA TELlES, Digesto Portuguez, Vol. I, 5th ed., Coimbra, 1860, book III, pp. 5-6

${ }^{15}$ Cf. CABRAL DE MONCADA, Lições de Direito Civil, Vol. II, 2nd ed., Coimbra, 1955, pp. 85-6.
}

insensitivity of jurists who so greatly minimised the legitimate interests of non-human animals that they even integrated them into the category of things. Furthermore, at the beginning of the 19th century, Lawrence rejected the idea of non-human animals as the object of mere compassion as, in his view, they should be duly covered with the mantle of justice appropriate to any living being. He, therefore, argued it was artificial to promote one justice for human animals and another one for non-human animals out of respect for the jus animaliu $^{16}$.

In turn, Salt, while working on attributing a legal status for animals that would irreversibly separate them from inanimate things, defended the entitlement of rights for non-human living beings, e.g. the rights to liberty and well-being. Already into the 20th century, this theme was resumed by Singer who, after highlighting the similarities in the animal and human capacities for suffering, set out the paradox that seeks to eliminate human suffering but does not avoid the pain and suffering of animals. Therefore, Singer defended equality in the interests of humans and animals by virtue of strict equivalence in the protection provided against pain and suffering $^{17}$ [44].

This approximation between human and non-human animal interests obviously conflicts with the stances taken under speciesism, species-based discrimination and anthropocentrism. Moreover, such positions have come in for severe criticism by the doctrine devoted to animal-related issues. Accordingly, Regan claims that all subjects, "subjectsof-a life", should be treated in the same way as they ultimately belong to the same community ${ }^{18}[40]$. Therefore, in accepting the existence of dissimilar interests between animals and human beings, Regan highlights the respect necessary to any equitable balance between rational and nonrational beings, noting the arbitrary nature of promoting the value of human beings in the name of any utilitarianism that thereby disqualifies the potentialities of animals ${ }^{19}$. Therefore, given the need to protect life, harm should be avoided and respect for the interests underlying any natural rights should be emphasised ${ }^{20}$. Moreover, even if one does not accept the single community argument, it would clearly be inappropriate either to reject the potential of animals ${ }^{21}$ or, as an advanced society, to live with maltreatment and cruelty that does not at least protect the dignity of any living being ${ }^{22}$ [17]. Nevertheless, as regards the harm of death, the harm to human life admittedly remained greater than that to animal life as the effect of the loss runs far higher ${ }^{23}$. Thus, in the context of his reflections, Regan subsequently makes a statement aimed at affirming certain animal rights, such as

\footnotetext{
${ }^{16}$ Cf. JOHN LAWRENCE, A Philosophical...op. cit., pp. 120 and fol.

${ }^{17}$ Cf. PETER SINGER, Animal Liberation, New York, 1975, pp. 29 and fol

${ }^{18}$ Cf. TOM REGAN, The Case for Animal Rights, Berkeley, 1983, p. 243.

${ }^{19}$ Cf. TOM REGAN, The Case...op. cit., p. 340.

${ }^{20}$ Cf. TOM REGAN, The Case...op. cit., pp. 342 and fol.

${ }^{21}$ Cf. TOM REGAN, The Case...op. cit., p. 356.

${ }^{22}$ Cf. GARY FRANCIONE, Introduction to Animal Rights, Philadelphia, 1999, pp. 84 and fol.

${ }^{23}$ Cf. TOM REGAN, The Case...op. cit., pp. 182 and fol.
} 
the right to life, the right to liberty and the right to wellbeing $^{24}$ [41].

However, while such progress on the densification of animal related issues remains undeniable, the same may not be concluded from any dispassionate analysis of established legal frameworks and, above all, especially as regards the Portuguese positive law. In effect, beyond the prescriptions of European Union law on the protection of animal wellbeing $^{25}$, at the beginning of the $21 \mathrm{st}$ century, we find prohibitions only on unjustified violence against animals ${ }^{26}$. There thus still remains a similarity between animals and things that has long since ended in other legal systems ${ }^{27}$. Thus, although some doctrine insists on the dissimilarities between animals and things ${ }^{28}$ and the Preliminary Reports on Civil Law Reform have, since 2005, signalled the importance of profoundly changing the animal theme ${ }^{29}$, the positive law has retained an irritating amorphism and with the jurisprudence here and there signalling an eminently conservative and sometimes clearly retrograde position ${ }^{30}$.

\section{The Animal Status}

The legal framework changed only with the entry into force of Law no. 8/2017, which brought about significant changes in the articles of the Criminal, Civil and Civil Procedure Codes and consequently establishes a legal status for the animal. For our purposes here, we shall focus only on the changes inserted in the Civil Code (CC) in order to assess the consequences directed towards animals, characterised as living beings endowed with sensitivity. First of all, it is important to underline that the new legal regime drives modifications to some of the precepts and the addition of others, located both in the General Section and in Book III of

${ }^{24}$ Cf. TOM REGAN, Animal Rights, Human Wrongs, Lanham, 2003, pp. 31 and fol.

${ }^{25} \mathrm{Cf}$. Protocol no. 33 on the protection and well-being of animals of the European Union annexed to the 1997 Amsterdam Treaty

${ }^{26} \mathrm{Cf}$. Law $92 / 95$ of 12 September

${ }^{27}$ In the Austrian Civil Code (ABGB), a new paragraph ( $\$ 285$ a) was introduced in 1988 to specifically determine that animals are not things. Shortly afterwards, more precisely in August 1990, the German Civil Code (BGB) also received a paragraph ( $\$ 90$ a) inserted with similar content. Later, in 1999, it was the turn of the French Civil Code to highlight, through an amendment to Article 524, animals over other appropriable and transformable objects.

${ }^{28}$ MENEZES CORDEIRO defended that the notion of thing corresponds to an inanimate object. This would, therefore, be useless for characterising the animal. See Tratado de Direito Civil Português, Vol. III, Coimbra, 2000, pp. 224-5. In a similar sense, see our "Animal: Coisa ou Tertium Genus" in Estudos Dedicados ao Professor Doutor Carvalho Fernandes, Vol. II, Lisbon, 2011, pp. 250 and fol.

${ }^{29}$ Three of the Preliminary Reports, drawn up under the Protocol signed between the Ministry of Justice's Legislative Policy and Planning Office (GPLP) and the Law Faculties of the University of Coimbra, the University of Lisbon, the Portuguese Catholic University and the Nova University of Lisbon advocate an amendment to the Civil Code in order to put an end to the equation between things and animals. Cf. Reforma do Direito Civil: Relatórios Preliminares, Ministério da Justiça, Coimbra, 2005, pp. 27 and fol.

${ }^{30}$ Under a judgment handed down on 23 September 2010, the Supreme Administrative Court declared that animals are not entitled to rights so as to justify pigeon shooting as a legitimate and lawful sporting activity. See our "Tiro aos Pombos: Uma Violência Injustificada" in Cadernos de Justiça Administrativa, no. 87, May, 2011, p. 39. the CC. Accordingly, even prior to the provision characterising the thing, Article $202^{\circ}$, there are Articles $201^{\circ}$ $\mathrm{B}, 201^{\circ} \mathrm{C}$ and $201^{\circ} \mathrm{D}$. Now, despite the criticism directed at the notion of thing throughout the bulk of this doctrine, the legislator still insists on the conceptual key when, in Article $201 \mathrm{~B}$, states that animals are living beings endowed with sensitivity and the object of legal protection by virtue of their nature. In article $201{ }^{\circ} \mathrm{C}$, the legislator then adds that the legal protection of animals operates according to the terms of the provisions of the $\mathrm{CC}$ and special legislation. Moreover, Article $201^{\circ} \mathrm{D}$ determines, in the absence of any special law, the subsidiary applicability of the provisions regarding things

Secondly, as regards Book III, the Law of Things, the precept regarding the ownership of animals, Article $1305^{\circ} \mathrm{A}$, stands out in coming immediately after Article $1305^{\circ}$ on the ownership of things. In these terms, should the owner of things benefit from, in a full and exclusive manner, the rights of use, fruition and disposal, the owner of animals must ensure the welfare and characteristics of each species. The owner must accordingly guarantee access to water, food and veterinary medical care and may not, without legitimate reason, inflict pain or mistreatment that causes unjustified suffering, abandonment or death. In addition, article $1318^{\circ}$, concerning occupation, and article $1323^{\circ}$, concerning finding, experienced important modifications in order to terminate the assimilation between the animal and the thing. However, the remaining precepts were left almost immutable, with the exception of the right of retention in cases of grounded fears of animals becoming victims of maltreatment by their owner as stipulated by $\mathrm{CC}$ article $1323^{\circ}$ paragraph 7 .

As we have written on another occasion, the $\mathrm{CC}$ reform seems tentative, confusing and disappointing ${ }^{31}$, especially in view of the immense expectations created and the just concerns of contemporary animal rights issues. In fact, if the amendments introduced into the $\mathrm{CC}$ articles had the leitmotiv of ending the equation between thing and animal, this task was carried out with neither efficacy nor dedication. In fact, while there may be positive and encouraging aspects, we also encounter many other contradictory and very disappointing points. As regards the positive news, we may highlight the differences between the notion of thing and animal as well as the flagrant dissimilarities within the content of the precepts relating to property. In terms of the contradictory and negative aspects, given the dissimilarity between things and animals, it seems surprising and even paradoxical that the law of things effectively remains applicable, albeit in a subsidiary capacity, to the legal status of animals. Therefore, despite ending the equivalence between things and animals and the impressive differentiation between the content of the entitlement of things and animals, there still remains an inexplicable and contradictory applicability of the law of things, on a subsidiary basis, to the legal status of the animal. In other words, should animals no longer be equated to things, with distinct and different entitlements, the regime ends up being

\footnotetext{
${ }^{31}$ See our Manual de Direitos Reais, 2nd ed., Lisbon, 2020, p. 75
} 
reconducted, to a very significant and very predominant extent, to the legal regime in effect for tangible things.

Despite these unavoidable setbacks, it is interesting to look in more detail at the positive aspects listed above. One such facet naturally encapsulates the legal notion of animal. In fact, simply by stating that the animal is a living being endowed with sensitivity and the object of legal protection by virtue of its nature, the $\mathrm{CC}$ opens up an abyssal difference in relation to the universe of tangible things, as inanimate objects, devoid of life and sensitivity. Another relevant aspect, in line with this differentiation between thing and animal, will certainly derive from the precept regarding the entitlement of animals. In fact, the duties around ensuring the well-being of animals and respect for the characteristics of each species contrast enormously with the usage and fruition, fully and exclusively, of each tangible thing. We should also recall how the CC specifies the duty of animal welfare with stipulated guarantees over access to water, food and medical care. Furthermore, that animal entitlement precludes the corresponding possibility of inflicting, without legitimate reason, pain, suffering or any other mistreatment that causes unjustified suffering, abandonment or death.

As may easily be grasped, such aspects, especially those relating to animal entitlement, appear radically different and substantially differentiate from the use of tangible things. Therefore, despite some surprising opinions to the contrary, they very much separate the relationship of strict dominance between animals and their owners. In fact, it was exactly for this same reason that the legislator deemed it necessary to highlight two precepts, and not only one, about the content of property. Thus, on the one hand, there is the ownership of things while the very next article deals with the ownership of animals. As is understandable, we prefer to adopt the term entitlement as we do not believe the contents of article $1305^{\circ}$ A allow us to qualify the respective legal nature as property. Accordingly, even while very well knowing that property contains only a very limited scope, very distant from the classic legal adage usus, fructus and abusus, we must underline that the set of characteristics and identity facets of the rights over property, specifically regarding usage and fruition are naturally very distant from the duties to assure well-being or to avoid the pain or abandonment of animals. In short, should the content of the rights of property encompass the powers of usage, fruition, transformation, claim and exclusion $^{32}$ [48], they do not in the least conform to the limits resulting from the precept on animal entitlement. Even when accepting the indeterminate powers of owners ${ }^{33}$ [25], not even then do we come close to accepting the complex duties attached to animal entitlement in accordance with the provisions stipulated by Article $1305^{\circ}$ A. Furthermore, even when accepting several properties ${ }^{34}$ [13], it does not seem to us

\footnotetext{
${ }^{32}$ In this sense, JOSÉ ALBERTO VIEIRA, Direitos Reais, 3rd ed., Coimbra, 2020, p. 608.

${ }^{33}$ MENEZES LEITÃO identifies, as a characteristic of the right of property, an indeterminate character that would attribute an unlimited series of faculties to the respective holder. Cf. Direitos Reais, 6th ed., Coimbra, 2017, p. 264.

${ }^{34}$ Cf. RUI PINTO DUARTE, Curso de Direitos Reais, 4th ed., Cascais, 2020, p.
}

that animal ownership resembles something clearly designed to affect inanimate objects, tangible things, or be geared to special forms of ownership, such as industrial property or various special forms of social bonding ${ }^{35}[10]$.

Therefore, from our point of view, such modifications regarding the animal statute inserted into the articles of the $\mathrm{CC}$, although tentative and insufficient, end up assuming an enormous level of significance. In fact, not only do they put an end to the incomprehensible and antiquated equation between a thing and an animal but they also terminate, in an ineluctable fashion, the logic of strict dominance over animals. In this aspect, we should recall that animals are living beings endowed with sensitivity and, therefore, in need of special legal protection due to their particular natures.

We must admit that these conclusions are neither surprising nor markedly innovative. In fact, detaching the logic of dominance has been proclaimed, in a convincing and insistent fashion, by scholars specialising in the animal issue. Thus, when Francione studied animal welfare, he argued that the most effective way to break the cycle of exploitation would be to eradicate the proprietary status then still prevailing over animals ${ }^{36}$. Other authors then took up a similar approach. In particular, Favre, after recalling that the Antarctic, the Moon and wild animals lack owners, wonders about the exact entitlement that falls on cat $\mathrm{Zoe}^{37}$ [16]. Next, after trying to demonstrate the nonconformity and cruelty of turning the focus of property towards domestic animals but not, obviously, towards rocks and stones ${ }^{38}$ [16], this author stresses the urgent need to reform the relevant legislation in order to introduce new mechanisms, such as the institution of trust for animals ${ }^{39}[16]$.

Hence, in this way, faced by the abyssal non-conformity in relation to the canons of dominance, there have been various attempts to pursue alternative paths to that of eminent property and dominance ${ }^{40}$ [4]. In order to assess not only the dissimilarities of the bond in relation to property, even if revisited by more modern theories of dominance, this also strives to reaffirm the validity of stripping away the tangible thing. This especially holds as these alternatives, when moving away from the old status quo destined to equating animals with things, are based on postulates of an ethical, philosophical or ideological nature that affirm not only the terminus of anthropocentrism but also other aspects tending to disconnect the animal from the logic of belonging and thereby more effectively promoting the respective well-being, absence of pain and suffering.

56.

${ }^{35}$ Cf. FERNANDO ALVES CORREIA, O Plano Urbanístico e o Princípio da Igualdade, Coimbra, 1989, pp. 308-9.

${ }^{36}$ Cf. GARY FRANCIONE, Introduction...op. cit., pp. 85 and fol.

${ }^{37}$ Cf. DAVID FAVRE, "Equitable Self-Ownership for Animals" in Duke Law Journal, no. 50, pp. 480 and fol.

${ }^{38}$ Cf. DAVID FAVRE, "Equitable..." in op. cit., p. 483.

${ }^{39}$ Cf. DAVID FAVRE, "Equitable..." in op. cit., p. 494 and fol.

${ }^{40}$ Cf. KAREN BRADSHAW, "Animal Property Rights" in University of Colorado Law Review, no. 89, 2018, pp. 810 and fol. 


\section{Animal as a Subject of Rights}

Before proceeding with the purpose of deepening the consequences stemming from removing the tangible thing, it is first important to reflect on the legal nature of animals, non-human living beings, within the scope of the changes in the CC brought about by Law No. 8/2017. While, prior to these changes, the identification between the animal and the thing gained significant adherence ${ }^{41}[2,6,23]$, even while never attaining unanimity ${ }^{42}$ [34], after the entry into effect of those amendments, we find an apparent majority, more formal than substantive, in favour of ending the assimilation between animal and thing. Indeed, despite that majority understanding, many still insist on the idea that the animal continues to be an object of rights. Others differ and prefigure animals as a subject of rights. Furthermore, there is now a third doctrinal current attempting to establish an intermediate path, an authentic tertium genus, positioned between people, subjects of rights, and the tangible things, inanimate objects.

As regards the first position, Barreto Menezes Cordeiro states animals may have ceased to be things in the strict sense but they have not lost this designation in the broad sense ${ }^{43}$ [7]. Consequently, he prefers the term object, rather than thing in the broad sense while concluding that animals are objects of rights $^{44}$. Adopting a similar position, Paulo Mota Pinto, although admitting the extension of the personality does not degrade the personality itself, defends that even after the autonomisation of the thing and the animal, the latter continues to be the object of rights ${ }^{45}$ [36]. Sá e Mello, although departing from different assumptions and open to the positive consequences of a future encapsulating the possible existence of subjective rights, nevertheless still ends up concluding that animals are the object of legal relations ${ }^{46}$

\footnotetext{
${ }^{41}$ Cf. OLIVEIRA ASCENSÃO, Direito Civil: Reais, 5th ed., Coimbra, 1993, pp. 451 and fol. JOSÉ ALBERTO VIEIRA, Direitos Reais, Coimbra, 2008, pp. 713 and fol. ANTÓNIO SANTOS JUSTO, Direitos Reais, 3rd ed., Coimbra, 2011, pp. 254 and fol. FILIPE CABRAL, Fundamentação dos Direitos dos Animais, Alcochete, 2015, pp. 208 and fol.

${ }^{42}$ ANDRÉ DIAS PEREIRA maintains that the animal is a sui generis thing, basing such an assertion on how the legislator has prescribed, down through time, several special animal focused regimes. See "Tiro aos Pombos na Jurisprudência Portuguesa" in Cadernos de Direito Privado, no. 12, 2005, pp. 43 and fol. MENEZES CORDEIRO, in turn, accepts that the introduction of $\$ 90$ a into the BGB officialised the understanding that the animal is a sui generis thing. See Tratado de Direito Civil, Tomb III, 3rd ed. On the contrary, according to a previous study of ours, there is every relevance in advancing further than the category of a simple tertium genus. Therefore, we correspondingly accept the possibility of the animal being a subject of rights. See our "Animal: Coisa ou Tertium Genus?" in Estudos Dedicados ao Professor Luís Alberto Carvalho Fernandes, vol. II, Lisbon, 2011, pp. 252 and fol.

${ }^{43}$ BARRETO MENEZES CORDEIRO shares an understanding that distinguishes between the thing in a broad, proper sense and in a strict sense. Cf. "A Natureza Jurídica dos Animais à Luz da Lei no. 8/2017, of 3 March, in Revista de Direito Civil, Year 2, no. 2, 2017, pp. 330 and fol.

${ }^{44}$ BARRETO MENEZES CORDEIRO, “A Natureza...” in op. cit., pp. 333 and fol.

${ }^{45}$ Cf. PAUlO MOTA PINTO, "Estatuto Jurídico Civil dos Animais", in Direito dos Animais, 2018, available at www.cej.mj.pt

${ }^{46}$ According to ALBERTO SÁ E MELLO, the consideration of subjective rights, in the entitlement of animals faces not only the impossibility of ascertaining the
}

[29]. Therefore, even while accepting animals are sentient beings, this does not necessarily imply a valuation that implies changing their legal status ${ }^{47}$. On the other hand, António Menezes Cordeiro, although accepting that the personalisation of animals does not necessarily repulse civilists, defends how it remains wiser to adhere to Barreto Menezes Cordeiro's position and he accordingly declares himself in agreement with the characterisation of animals as objects of rights ${ }^{48}$.

The idea that animal should be neither objectified nor humanised but rather be integrated a third category, a tertium genus, was strengthened and deepened, especially in Germany following the insertion of $\$ 90 \mathrm{a}$ in the BGB. In other words, as the animal is a living being, a creature of God, it cannot have its position degraded to the level of an object even while it cannot also be humanised ${ }^{49}$ [5]. In Portugal, André Dias Pereira put forward the precursor to this strand of thought when, after alluding to the existence of various special regimes dedicated to animals and the shortcomings in the classification of things, he then stated that the animal is a sui generis thing, a true tertium genus ${ }^{50}$. Subsequently, Hörster adopted a similar path in admitting that animals are no longer tangible things but are to be considered sui generis objects of the law ${ }^{51}$ [22]. Adopting another perspective, Helena Telino Neves, somewhat surprisingly, reiterated how animals must be sui generis things ${ }^{52}$ [31]. In a second period of time, subsequent to the 2017 reform, it is hardly surprising that this theory has again been taken up in view of the difficulties of choosing when faced by the dichotomy between person and thing. Thus, according to Filipe Albuquerque de Matos and Mafalda Miranda Barbosa, the amendments introduced in the $\mathrm{CC}$ underpin the understanding according to which the status of animals corresponds to a tertium genus, a third category between persons and things ${ }^{53}$ [28]. However, in further explaining their position, they state that animals cease to be things but still embody an object of legal relations ${ }^{54}$ [28]. Accordingly,

animal's will as regards the exercising of their rights but also the difficulty of reconciling its probable wishes with the interests of humans. Cf. "Os Animais no Ordenamento Jurídico Português: Algumas Notas" in the Revista da Ordem dos Advogados journal, Vol. No. 77, 2017, pp. 114 and fol.

${ }^{47}$ Cf. ALBERTO SÁ E MELLO, “Os Animais...” in op. cit., p. 116.

${ }^{48}$ Cf. MENEZES CORDEIRO, Tratado de Direito Civil, Vol. III, 4th ed., Coimbra, 2019, pp. 314-5.

${ }^{49}$ Accordingly, BIRGIT BRÜNINGHAUS refers to the animal as a mixed nature, the creator of tension and not part of the dualism between person and thing. Cf Die Stellung des Tieres im Bürgerlichen Gesetzbuch, Berlin, 1992, pp. 111 and fol ${ }^{50}$ Cf. ANDRÉ DIAS PEREIRA, "Tiro aos Pombos" na Jurisprudência Portuguesa" in Cadernos de Direito Privado, no. 12, 2005, pp. 43 and fol.

${ }^{51}$ Cf. HEINRICH HÖRSTER, A Parte Geral do Código Civil Português, Coimbra, 2011, pp. 175-6

${ }^{52}$ We express our surprise regarding the defensive position of HELENA TELINO NEVES when she opts for the category of sui generis things and, accordingly, rejects the attribution of rights to animals as in both these writings, as well as in her previous works, openly assume the defence of animal welfare and the revision of their respective legal status. Cf. A Controversa Definição da Natureza Jurídica dos Animais" in Animais: Deveres e Direitos, Lisbon, 2014, p. 89.

53 Cf. FILIPE ALBUQUERQUE MATOS AND MAFALDA MIRANDA BARBOSA, O Novo Estatuto Jurídico dos Animais, Coimbra, 2017, p. 7.

54 Cf. FILIPE ALBUQUERQUE MATOS AND MAFALDA MIRANDA 
although they highlight the hybridity of the animal status, they do not denote any radical departure from previous assumptions. In fact, as they refuse to attribute rights to animals, even while accepting the duties of people towards them ${ }^{55}$, they prefer to minimise the differences between animals and mobile things ${ }^{56}$. In short, after questioning the autonomy of animals in the face of the legal universe of things, they do not assume any equidistance, stating that the legal diploma of 2017 does not fundamentally separate animals from tangible things ${ }^{57}$.

We should point out that, even before the BGB reform, we may encounter positions in the German doctrine characterising the animal as a true subject of rights. These were significantly reinforced following the entry into force of $\S 90$ a. In these terms, regarding the period prior to the BGB reform, Erbel attempted to demonstrate how animals, as natural creatures constitutive of a unit of life, susceptible of delimitation and individualisation, constitute legal subjects ${ }^{58}$ [15]. Regarding the later period, it is only fair to highlight the contribution of Brüninghaus especially when he rightly emphasises the idea of co-creation, the similarity between the dignity of the animal and of the human being ${ }^{59}$ as well as the repositioning the animal as a true legal subject ${ }^{60}$. In turn, as far as the Portuguese doctrine is concerned, the work of Fernando Araújo stands out as regards animal interests as he distinguishes animal rights without any complexes or hesitation. He furthermore maintains that a point of no return has been reached beyond which it is important to refer to animal rights, effectively enforceable, under all circumstances, in relation to human individuals and the state itself $^{61}[1]$. On our own behalf, writing at a later point in time, we identified the crucial importance of distinguishing between animals and things, the insufficiency of the tertium genus category and in addition to the imperative of characterising the animal as a true legal subject ${ }^{62}$. Subsequently, after having found the 2017 CC reform disappointing, we again insisted on the need to reposition the

BARBOSA, O Novo Estatuto...op.cit., pp. 7-8.

${ }^{55}$ These would be indirect duties focused on the following objectives: the protection of humanity, the protection of the particular interests of some human beings and the safeguarding of good customs. Cf. FILIPE ALBUQUERQUE MATOS AND MAFALDA MIRANDA BARBOSA, O Novo Estatuto...op.cit., p. 69.

${ }^{56}$ Because of the subsidiary regime stipulated in very general terms under Article 201 D, FILIPE ALBUQUERQUE MATOS AND MAFALDA MIRANDA BARBOSA state that the distinction between animals and things was not even obvious to the legislators themselves. Cf. O Novo Estatuto...op.cit., p. 106.

57 Cf. FILIPE ALBUQUERQUE MATOS AND MAFALDA MIRANDA BARBOSA, O Novo Estatuto...op.cit., pp. 107-8.

${ }^{58}$ Cf. GUNTHER ERBEL, "Rechtsschutz für Tiere: Eine Bestandsaufnahme anlässlich der Novellierung des Tierschutzgesetzes" in Deutsches Verwaltungsblatt, 1986, p. 1254.

${ }^{59}$ BIRGIT BRÜNINGHAUS justifies mutual respect between human and animal life. Cf. Die Stellung...op. cit., p. 126.

${ }^{60}$ In this sense, BIRGIT BRÜNINGHAUS compares animals to new-born babies or mentally handicapped subjects to demonstrate how some people lack the capacity to exercise their rights but this does not remove their intrinsic quality as the subject. Cf. Die Stellung...op. cit., p. 127.

${ }^{61}$ Cf. FERNANDO ARAÚJO, A Hora ...op. cit., pp. 285-6.

${ }^{62}$ See our "O Animal..." in op. cit., p. 255. animal as a legal subject and correspondingly as a holder of rights $^{63}$. Accordingly, after recognising the subjective rights of animals, in particular the rights to life, to well-being and to the absence of pain, we warned of the extremely innovative position of some foreign jurisprudence in the sense of granting procedural legitimacy to animals and allowing them to litigate, in their own name, as subjects of rights and nonhuman persons ${ }^{64}$. We have also recalled other innovative trends, notably in artificial intelligence, trending towards attributing legal personalities to robots ${ }^{65}$. After having reviewed the literature on this subject, we have decided to reconfirm our position because, apart from due respect for dissimilar opinions, we do not find in the respective arguments any justifications that undermine our convictions. Some of the arguments put forward do not invalidate the subjectification of animals but rather propose conjunctural reasons ${ }^{66}$ intended either to sustain or perhaps to limit the more daring conclusions in line with current events.

\section{Atavisms and the Challenges of Animal Issues}

Irrespective of the questions concerning their legal nature, it is interesting to appraise, even if briefly, some atavisms that the animal problem faces as reported, it should be acknowledged, by some jurists who do not even accept the subjectivation of animals. On the other hand, we must also appreciate some vanguard reflections that naturally raise challenges to the rights under establishment no matter how much some atavistic customs or eminently conservative, even reactionary ideas, insist on looking at animals from a perspective similar to that of our eighteenth-century ancestors.

Thus, António Menezes Cordeiro, although he shares the conclusion that animals can be the object of rights, points out pigeon shooting and bullfighting as true "Iberian anomalies" $^{67}$. Accordingly, even if the $1966 \mathrm{CC}$, from its inception, was not able to keep up with the ethical and social realities of Western society in the second half of the 20th century ${ }^{68}$ [9], bullfighting did not even then appear defensible. Indeed, António Menezes Cordeiro, besides considering this a practice contrary to the cultural path of humanity $^{69}$, claims not to know of any serious legal-scientific contribution in defence of bullfighting ${ }^{70}$.

\footnotetext{
${ }^{63}$ See our Manual de Direitos Reais, 2nd ed., Lisbon, 2020, pp. 77 and fol.

${ }^{64}$ In this regard, we would refer to an important decision handed down in 2015 by the Administrative and Tax Litigation Court of the city of Buenos Aires which recognises that the orangutan Sandra was a subject of rights and a non-human person. Cf. Manual...op. cit., pp. 78-9.

${ }^{65}$ See our Manual... op. cit., p. 79.

${ }^{66}$ Hence, PAULO MOTA PINTO, after recognising the inexistence of any valid reason to rule out the subjectivation of animals then adds, by way of confession, that he has not yet taken "that leap". Cf. "Estatuto..." in op. cit.

${ }^{67}$ Cf. ANTÓNIO MENEZES CORDEIRO, Tratado...op. cit., pp. 316 and fol.

${ }^{68}$ Cf. ANTÓNIO MENEZES CORDEIRO, Da Modernização do Direito Civil, Coimbra, 2004, p. 57.

${ }^{69}$ Cf. ANTÓNIO MENEZES CORDEIRO, Tratado...op. cit., p. 316

${ }^{70}$ Cf. ANTÓNIO MENEZES CORDEIRO, Tratado...op. cit., p. 322.
} 
On this matter, it is important to recall the forthright attitude of António Maria Pereira, who always stood out in denouncing bullfighting as unethical and contrary to civilised values $^{71}$ [35]. Later, Carla Amado Gomes also strongly criticised bullfighting and even warning of the flagrant contradiction between such a "barbaric and undignified" practice and animal welfare ${ }^{72}$ [20]. From our perspective, we maintain that the contradiction is even more serious and insurmountable. In fact, although the preamble to DecreeLaw no. $89 / 2014^{73}$ states that bullfighting is an integral part of Portuguese culture, we also know that rites and traditions must not hinder the evolution of values in any given society ${ }^{74}$ [19]. Accordingly, as Paulo Ferreira da Cunha states, traditions, as heritage, must adapt to the values of the present $^{75}$ [11]. Moreover, as regards Portuguese positive law, we would here recall that Law no. 8 /2017 on the status of animals introduced substantive changes not only to the Civil Code but also to the Criminal Code. Therefore, there are such incompatibilities between animal welfare, animal rights, the criminalisation of ill-treatment and the practice of bullfighting that it would seem clear that bullfighting no longer holds legal support following the entry into force of the 2017 law. Whether they arise from the general regime, or even the exceptional regime that allowed the cruelty of deadly bullfights in the 21 st century ${ }^{76}$. The same applies to the bloodthirsty 'sport' of pigeon shooting. In fact, as we stated in an annotation to a judgment from the Supreme Administrative Court, it is not admissible to distinguish between barbaric and unjustified violence against animals, in general, and violence tout court, as accepted by this court, in order to exempt this bloody and reprehensible activity ${ }^{77}$.

Alongside such serious atavisms, it is interesting to note, by contrast, the most recent ethical, philosophical and ideological positions ${ }^{78}$ [26] that constitute challenges for the animal issue. We must therefore pay attention to positions directed at a theme that is, as already stated, high on the agenda. Accordingly, after the impressive questions posed by Richard Ryder $^{79}$ [42] and Peter Singer ${ }^{80}$ [45], in the closing

${ }^{71}$ Cf. ANTÓNIO MARIA PEREIRA, "Ética e Touradas" in Boletim da Ordem dos Advogados, no. 28, 2003, pp. 48 and fol.

${ }^{72}$ Cf. CARLA AMADO GOMES, "Direito dos Animais: Um Ramo Emergente" in Animais: Deveres e Direitos, Lisbon, 2014, p. 64.

${ }^{73}$ Cf. Decree-Law no. 89/2014 of 11 June approved the Regulation on Bullfighting

${ }^{74}$ Cf. LUCIA GASPARINI, Il Patrimonio Culturale Immateriale, Milan, 2014, pp 27 and fol.

${ }^{75}$ Thus, according to PAULO FERREIRA DA CUNHA, it is necessary to preserve traditions that align with the values of the present and reject those that run counter to them and are tied to archaic world views. Cf. Direitos Fundamentais: Fundamentos e Direitos Sociais, Lisbon, 2014, pp. 274-5.

${ }^{76}$ Cf. Lei no. 19/2002 of 31 July.

77 See our "Tiro aos Pombos: Uma Violência Injustificada" in Cadernos de Justiça Administrativa, no. 87, May, 2011, p. 39.

${ }^{78} \mathrm{On}$ the ethical and philosophical postulates of the animal problem since Antiquity, FERNANDO ARAÚJO, A Hora.op. cit, pp. 45 and fol. See our "O Animal." in op. cit, pp. 222 and fol. Still, JOSÉ AROSO DE LINHARES, "A Ética do Continuum das Espécies e a Resposta Civilizacional do Direito", in Boletim da Faculdade de Direito, Vol. 79, Coimbra, 2003, pp. 197 and fol. FILIPE CABRAL, Fundamentação. op. cit.p. 35.

${ }^{79}$ The origin of the term speciesism, in the sense of the right of supremacy of the decades of the 20th century in particular, we come across various highly pertinent reflections. In fact, it was not only Ryder and Singer who published new and more profound studies $^{81}[43,46]$ and we encounter several other positions of inestimable interest. Thus, in our view, the contributions of Regan, Lovelock and Francione should be highlighted first of all. Correspondingly, according to Regan, all life forms, as subjects of life or living beings, should receive similar treatment and respect by virtue of belonging to the same community $^{82}$. It therefore becomes important to reject any hierarchy among living beings so as to prevent the sacrifice of some in the interests of others ${ }^{83}$. Accordingly, while recognising distinct interests between animals and humans, Regan admits equal respect for all living beings; both rational and non-rational ${ }^{84}$. In another approach, Lovelock emphasises the importance of the development and wellbeing of living beings, both human and non-human ${ }^{85}$ [27]. Francione, in turn, not only alerts to the need to avoid pain, suffering and even the deaths of the animal but also stresses the imperious need to abolish, just as soon as might be feasible, the old and antiquated proprietary statute ${ }^{86}$.

We must concur that, following a markedly anthropocentrist emphasis, several other dominant ideas have emerged; specifically, speciesism, animal welfare and the defence of animal rights. In fact, all of these have taken this issue onto another level. Indeed, we should pay particular attention to the theories regarding the deepening of animal rights. Thus, after the turn of the 21 st century, Nussbaum wrote that the postulates of the theory of justice, advanced by John Rawls, should extend to non-human living beings ${ }^{87}$ [32].

human species to the detriment of the others, was applied by RICHARD RYDER back in the 1970s within the framework of shaking up the dominant status quo. Cf. Victims of Science, London, 1973, pp. 15 and fol.

${ }^{80}$ PETER SINGER also deployed the term speciesism in the $1970 \mathrm{~s}$ in order to claim respect for all living beings, defending a minimum level of equality even if he did not demand identical and strict equality between human beings and animals. Cf. Animal Liberation, New York, 1975, pp. 29 and fol. Later, in another work, he returned to the subject, placing racism and speciesism on an almost equal footing. Accordingly, while racists attribute great importance to the interests of their own race, speciesists award greater importance to the designs of members of their own species in the case of conflict between their own interests and those of other species. Cf. Practical Ethics, Cambridge, 1979, p. 78.

${ }^{81}$ Cf. RICHARD RYDER, Animal Revolution: Changing Attitudes Towards Speciesism, Oxford, 1989, pp. 21 and fol.; PETER SINGER, The Expanding Circle, Ethics and Sociobiology, Oxford, 1981, pp. 31 and fol.

${ }^{82}$ According to TOM REGAN, there is a need to take into account behaviours and desires, perception and memory, sensations of pain, pleasure and well-being or even the tastes and aims of a physical and psychic identity. Cf. The Case for Animal Rights, Berkeley, 1983, p. 243.

${ }^{83}$ Cf. TOM REGAN, The Case...op. cit., pp. 235 and fol.

${ }^{84}$ According to TOM REGAN, the interests of animals could be neither reduced nor limited in accordance with the interests of human beings. Cf. The Case...op. cit., p. 356.

${ }^{85}$ Cf. JAMES LOVELOCK, Ages of Gaia, Oxford, 1988, pp. 21 and fol.

${ }^{86}$ GARY FRANCIONE, after maintaining animals have the right not to experience suffering and the right to individual development, argues that these rights prevent animals from being treated either as things or as part of the property of human beings. Cf. Introduction to Animal Rights: Your Child or the Dog?, Philadelphia, 1999, pp. 130 and fol.

${ }^{87}$ Cf. MARTHA NUSSBAUM, Frontiers of Justice, London, 2006, pp. 273 and fol. 
Consequently, this not only repudiates utilitarian theories, which undermine the basic principles of justice and animal suffering $^{88}$, but also strives to reformulate the social contract in order to include the complexity of the animal problematic $^{89}$. Therefore, after highlighting the aptitudes and faculties of humans, Nussbaum enumerates a very impressive list of animal faculties in order to demonstrate the existence of a broad community composed of human and non-human animals ${ }^{90}$.

Garner, in turn, also departs from the postulates of Rawls while proposing another theoretical construction, less ambitious and more realistic, for framing the rights of animals in a non-ideal world ${ }^{91}$ [18]. In other words, this would represent the actual world, full of contradictions, limits and real constraints. Accordingly, after relativising the most flagrant violations of the real world, he believes it possible to move towards ideal positions that are much more favourable $^{92}$ [18]. In summary, the theory of the non-ideal world would constitute a path, a process, even a springboard, to a much more refined stage of awareness about ethics, justice and animal rights ${ }^{93}$ [12].

Furthermore, Donaldson and Zymlicka take another far more ambitious position. In effect, they seek to reformulate the theory of citizenship in order to advocate a mixed society, composed of people and animals ${ }^{94}$. Accordingly, as regards domesticated animals, they are placed in a higher category as non-human living beings ${ }^{95}$. Regarding wild animals, as they live separately from the mixed human-animal society, the authors advocate the recognition of a special sovereignty over their own territory ${ }^{96}$. At a later stage, after responding to criticism of their book Zoopolis, they repeat the previous argument in order to consolidate the main idea of citizenship attributed to domestic animals ${ }^{97}$. Therefore, those animals would have the right to an identity, residence, protection and medical care on the grounds of contributing in some way to the welfare of the community ${ }^{98}$.

In another contribution, Ladwig, after stressing how the Donaldson and Zymlicka theory of citizenship assumes not

\footnotetext{
${ }^{88}$ In this sense, MARTHA NUSSBAUM criticises the inadequacy of Kantian thought. Cf. Fontiers...op. cit., pp. 328 and fol.

${ }^{89}$ Cf. MARTHA NUSSBAUM, Frontiers...op. cit., 331 and fol.

${ }^{90}$ After listing emotions, sensory capacities and interdependence with other species as animal aptitudes, MARTHA NUSSBAUM seeks to demonstrate the existence of a broad community of humans and non-humans. Cf. Frontiers...op. cit., pp. 346 and fol.

${ }^{91}$ Cf. ROBERT GARNER, A Theory of Justice for Animals: Animal Rights in a Nonideal World, Oxford, 2013, pp. 1 and fol.

${ }^{92}$ Cf. ROBERT GARNER, $A$ Theory...op. cit., pp. 10 and fol.

${ }^{93}$ Cf. SUE DONALDSON AND WILL KYMLICKA, Zoopolis: A Political Theory of Animal Rights, Oxford, 2013, pp. 19 and fol.

${ }^{94}$ Cf. SUE DONALDSON AND WILL KYMLICKA, Zoopolis: A Political Theory of Animal Rights, Oxford, 2013, pp. 19 and fol.

${ }^{95}$ Cf. SUE DONALDSON AND WILL KYMLICKA, Zoopolis...op. cit., pp. 73 and fol.

${ }^{96}$ Cf. SUE DONALDSON AND WILL KYMLICKA, Zoopolis...op. cit., pp. 156 and fol.

${ }^{97}$ Cf. SUE DONALDSON AND WILL KYMLICKA, "Animals and the Frontiers of Citizenship” in Oxford Journal of Legal Studies, Vol. 34, 2014, pp. 204 and fol.

${ }^{98}$ Cf. SUE DONALDSON AND WILL KYMLICKA, "Animals..." in op. cit., pp. 205-6.
}

only negative content but also includes positive duties towards a given community, wonders about the feasibility of domestic animals contributing to the common $\operatorname{good}^{99}$ [24]. Thus, regarding the example of sheep contributing with their wool to the community, Ladwig warns that there is no further correlating interest in the common good on the part of sheep $^{100}$ [24]. On the subject of wild animals, Ladwig refuses to grant them any entitlement to their own habitat or to recognise their sovereignty over the territories in which they live ${ }^{101}$.

\section{Conclusions}

In approaching the belated, confused and incipient 2017 $\mathrm{CC}$ reform, we would nevertheless note its proclamation that animals are living beings, endowed with sensitivity and the object of legal protection by virtue of their inherent nature. As well as aiming at safeguarding animal welfare and respect for the characteristics of each species, this naturally moves on from an eminent logic of propriety and dominance. We should duly remember that the traditional powers of usage, fruition and transformation of a tangible thing stand out as radically different from the duties imposed on the holder of an animal.

Concerning the legal nature, we refute the theory that proclaims the end of the equivalence between animals and things but that then, in a secondary phase, attempts to reconduct the animal to being a simple object of rights. We understand this construction to be simultaneously artificial and contradictory because this does not remove the animal from the universe of things and accordingly refusing to be consistent with either the end of assimilation or the challenges of modernity. This aspect is to a certain extent shared by those who defend a third way or tertium genus. Indeed, as we have seen above, despite separating animals from things, this position ends up reconducting them, as a last resort, to mere objects of legal relations. Logically, we have to recognise the insufficiency of the third way and admit that the indispensable and unavoidable subjectification of the animal repositions it as an authentic legal subject and thus unavoidably holding rights.

The cruel "sporting" activity of pigeon shooting and the supposedly cultural tradition of bullfighting both represent examples of a worrying atavism which must be eradicated as soon as possible. In both cases, there are no ethical, philosophical or legal grounds for their continued existence. Moreover, in legal terms, after the entry into force of Law no. $8 / 2017$, we believe that any bullfighting or pigeon shooting activities, carried out in any part of the national territory, is blatantly illegal.

It is important to emphasise how the most significant reflections on this problematic present, as their common

\footnotetext{
${ }^{99}$ Cf. BERND LADWIG, Politische Philosophie der Tierrechte, Berlim, 2020, p. 338 and fol.

${ }^{100}$ Thus, as noted by BERND LADWIG, the effective use of this wool would not be a matter of concern to the sheep. Cf. Politische...op. cit., p. 341

${ }^{101}$ Cf. BERND LADWIG, Politische...op. cit., pp. 345-6.
} 
denominator, the statement that animals are holders of rights. Indeed, the positionings of Singer, Regan, Lovelock or Francione's, as well as the theories later defended by Nussbaum, Garner, Donaldson, Zymlicka and Ladwig present animal rights as an undeniable and undisputable matrix. In fact, both the less ambitious theories, such as that defending a non-ideal world, led by Garner, and the more visionary perspectives, particularly those reflecting on an idea of citizenship or animal community as authored by Donaldson and Zymlicka, adopt the existence of animal rights as a shared assumption.

\section{References}

[1] ARAÚJO, Fernando, A Hora dos Direitos dos Animais, Coimbra, 2003.

[2] ASCENSÃO, Oliveira, Direito Civil: Reais, 5th ed., Coimbra, 1993.

[3] BONFANTE, Pietro, Corso di Diritto Romano, Vol. II, Milan, 1968.

[4] BRADSHAW, Karen, "Animal Property Rights" in University of Colorado Law Review, no. 89, 2018, pp. 810-861.

[5] BRÜNINGHAUS, Birgit, Die Sttellung des Tieres im Bürgerlichen Gesetzbuch, Berlin, 1992.

[6] CABRAL, Filipe, Fundamentação dos Direitos dos Animais, Alcochete, 2015.

[7] CORDEIRO, Barreto Menezes, "A Natureza Jurídica dos Animais à Luz da Lei no. 8/2017, of 3 March, in Revista de Direito Civil, Year 2, no. 2, 2017, pp. 317-336.

[8] CORDEIRO, António Menezes, Tratado de Direito Civil Português, Vol. III, Coimbra, 2000.

[9] CORDEIRO, António Menezes, Da Modernização do Direito Civil, Coimbra, 2004, p. 57

[10] CORREIA, Fernando Alves, O Plano Urbanístico e o Princípio da Igualdade, Coimbra, 1989.

[11] CUNHA, Paulo Ferreira da, Direitos Fundamentais: Fundamentos e Direitos Sociais, Lisbon, 2014.

[12] DONALDSON, Sue e Will Kymlicka, Zopopolis: A Political Theory of Animal Rights, Oxford, 2013.

[13] DUARTE, Rui Pinto, Curso de Direitos Reais, 4th ed., Cascais, 2020.

[14] ECKSTEIN, Ernst, "Das Schatz und Fundregal und seine Entwicklung in den deutschen Rechten" in Mitteilungen des Instituts für österreichische Geschichtsforschung, no. 31, 1910, pp. 193-204.

[15] ERBEL, Gunther, "Rechtsschutz für Tiere: Eine Bestandsaufnahme anlässlich der Novellierung des Tierschutzgesetzes" in Deutsches Verwaltungsblatt, 1986, p. 1254.

[16] FAVRE, David, "Equitable Self-Ownership for Animals" in Duke Law Journal, no. 50, pp. 473-502.

[17] FRANCIONE, Gary, Introduction to Animal Rights,
Philadelphia, 1999.

[18] GARNER, Robert, A Theory of Justice for Animals: Animal Rights in a Nonideal World, Oxford, 2013.

[19] GASPARINI, Lucia, Il Patrimonio Culturale Immateriale, Milan, 2014.

[20] GOMES, Carla Amado, "Direito dos Animais: Um Ramo Emergente" in Animais: Deveres e Direitos, Lisbon, 2014, pp. 48-67.

[21] HEUSLER, Andreas, Institutionen des deutschen Privatrechts, Vol. I, Leipzig, 1885.

[22] HÖRSTER, Heinrich, A Parte Geral do Código Civil Português, Coimbra, 2011.

[23] JUSTO, António Santos, Direitos Reais, 3rd ed., Coimbra, 2011.

[24] LADWIG, Bernd, Politische Philosophie der Tierrechte, Berlim, 2020.

[25] LEITÃO, Menezes, Direitos Reais, 6th ed., Coimbra, 2017.

[26] LINHARES, José Aroso de, "A Ética do Continuum das Espécies e a Resposta Civilizacional do Direito", in Boletim da Faculdade de Direito, Vol. 79, Coimbra, 2003, pp. 197-216.

[27] LOVELOCK, James, Ages of Gaia, Oxford, 1988.

[28] MATOS, Filipe Albuquerquee Mafalda Miranda Barbosa, $O$ Novo EstatutoJurídico dos Animais, Coimbra, 2017.

[29] MELLO, Alberto Sá e "Os Animais no Ordenamento Jurídico Português: Algumas Notas" in the Revista da Ordem dos Advogados journal, Vol. No. 77, 2017, pp. 95-116.

[30] MONCADA, Cabral de, Lições de Direito Civil, Vol. II, 2nd ed., Coimbra, 1955.

[31] NEVES, Helena Telino, A Controversa Definição da Natureza Jurídica dos Animais" in Animais: Deveres e Direitos, Lisbon, 2014, pp. 81-89.

[32] NUSSBAUM, Martha, Frontiers of Justice, London, 2006.

[33] PALANDT, Otto, Bürgerliches Gesetzbuch Kommentar, 47th ed., Munich, 1988

[34] PEREIRA, ANDRÉ DIAS, "Tiro aos Pombos na Jurisprudência Portuguesa" in Cadernos de Direito Privado, no. 12,2005 , pp. 41-45.

[35] PEREIRA, António Maria, "Ética e Touradas" in Boletim da Ordem dos Advogados, no. 28, 2003, pp. 47-55.

[36] PINTO, Paulo Mota, "Estatuto Jurídico Civil dos Animais", in Direito dos Animais, 2018, available at www.cej.mj.pt.

[37] RAMOS, José Luís, "Animal: Coisa ou Tertium Genus" in Estudos Dedicados ao Professor Doutor Carvalho Fernandes, Vol. II, Lisbon, 2011, pp. 221-256.

[38] RAMOS, José Luís, "Tiro aos Pombos: Uma Violência Injustificada" in Cadernos de Justiça Administrativa, no. 87, May, 2011, pp. 29-41.

[39] RAMOS, José Luís, Manual de Direitos Reais, 2nd ed., Lisbon, 2020 
[40] REGAN, Tom, The Case for Animal Rights, Berkeley, 1983.

[41] REGAN, Tom, Animal Rights, Human Wrongs, Lanham, 2003.

[42] RYDER. Richard, Victims of Science, London, 1973.

[43] RYDER, Richard, Animal Revolution: Changing Attitudes Towards Speciesism, Oxford, 1989.

[44] SINGER. Peter, Animal Liberation, New York, 1975.

[45] SINGER, Peter, Practical Ethics, Cambridge, 1979.
[46] SINGER, Peter, The Expanding Circle, Ethics and Sociobiology, Oxford, 1981.

[47] TELLES, Correa, Digesto Portuguez, Vol. I, 5th ed., Coimbra, 1860.

[48] VIEIRA, José Alberto, Direitos Reais, 3rd ed., Coimbra, 2020.

[49] VON BRINZ, Alois, Lehrbuch der Pandektn, Vol. I, $2^{\text {nd }}$ ed. Erlangen, 1887. 